\title{
Measuring the sosial economic benefits of Jabres cattle keeping in Bantarkawung Sub-district, Brebes, Central Java, Indonesia
}

\author{
M. S. Haq ${ }^{1}$, I. G. S. Budisatria ${ }^{1, *}$, P. Panjono ${ }^{1}$ and D. Maharani ${ }^{2}$ \\ ${ }^{1}$ Department of Animal Production, Faculty of Animal Science, \\ Universitas Gadjah Mada, Jl. Fauna No. 3, Yogyakarta - Indonesia \\ ${ }^{2}$ Department of Animal Breeding and Reproduction, Faculty of Animal Science, \\ Universitas Gadjah Mada, Jl. Fauna No. 3, Yogyakarta - Indonesia \\ *CorrespondingE-mail: budisatria@ugm.ac.id
}

Received February 18, 2019; Accepted May 15, 2019

\begin{abstract}
ABSTRAK
Penelitian ini bertujuan untuk mengeksplorasi kebermanfaatan sosial ekonomi sapi Jabres sebagai ternak lokal potensial pada dua zona ekologi di Kecamatan Bantarkawung, Brebes, yaitu zona dataran rendah dan dataran sedang. Pengambilan data dilakukan dengan metode Participatory Rural Appraisal (PRA), yaitu pendekatan yang melibatkan keluarga atau individu untuk menganalisis realita dari kondisi kehidupannya. Penelitian ini melibatkan 60 peternak dipilih secara purposive sampling berdasarkan 3 pertimbangan. Model analisis yang digunakan untuk menguji perbedaan adalah analisis independent Ttest. Hasil penelitian menunjukkan usia peternak pada zona dataran sedang lebih muda dibandingkan dataran rendah, sehingga tujuan pemeliharaan sebagai tabungan lebih tinggi pada dataran rendah $(2.90 \pm 0.31)$ dan sebaliknya tujuan pemeliharaan ternak sebagai sumber penghasilan lebih tinggi pada dataran sedang (2.23 \pm 0.50$)$. Hal ini diperkuat dengan nilai produksi bersih $(185 \pm 27 \mathrm{~kg} / \mathrm{tahun})$, nilai

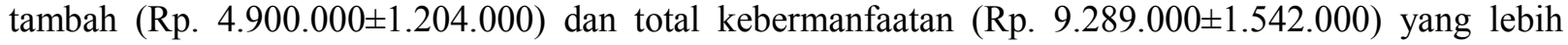
tinggi pada dataran sedang dibandingkan pada dataran rendah. Berdasar nilai tersebut disimpulkan bahwa peternak pada dataran sedang mampu lebih berpotensi untuk mempertahankan keberlanjutan peternakannya daripada petani pada dataran rendah.
\end{abstract}

Kata kunci: kebermanfaatan sosil dan ekonomi, profil peternak, sapi Jabres

\begin{abstract}
This study aimed to explore the socio-economic benefits of Jabres cattle as potential local livestock in two agro ecological zones, lowlands and middle zone in Bantarkawung Sub-District, Brebes, Central Java. The data were collected by Participatory Rural Appraisal (PRA) method, which is an approach to families or individuals to analyze the reality of their living conditions. This study involved 60 farmers which selected by purposive sampling based on three considerations. The analytical model used to test differences is the analysis of independent T-test. The result showed that the farmers in the middle zone are younger and most of their cattle keeping motivation are for livelihood. Meanwhile, the farmers in the low lands are older and most of their cattle keeping motivation is for saving only (2.90 \pm 0.31$)$. This condition caused the socio-economic benefit difference between those locations where the value of net production $(185 \pm 27 \mathrm{~kg} / \mathrm{y}$ ), added value (IDR 4.900.000 $\pm 1.204 .000)$, and total benefits (IDR 9.289.000 $\pm 1.542 .000)$ were higher in the medium land than in the lowlands. Based on these reasons, it can be concluded that middle zone farmers have more possibility to sustain their farm than those of
\end{abstract}


lowlands farmers.

Keywords: farmers profile, Jabres cattle, socio-economic benefit

\section{INTRODUCTION}

Cattles as one of the main meat producers have an important role in driving the economy. It not only moves the economy nationally, but also affects farmers. Population growth, population displacement and livelihood enhancement increase the food demand, especially those from animals. This is certainly an opportunity to develop animal husbandry, especially for small and medium farms as one of the suppliers for meat demand. Brebes Regency, one of the areas in Central Java, has the potential of local livestock, namely Jabres cattle. It can live in two agro ecological zones, lowlands and middle zone, which cover most of Brebes Regency. The lowlands are found at less than 100 meters above sea level with average annual rainfall is $2491 \mathrm{~mm}$. The lowlands are characterized by paddy fields. The middle zones are defined as the area between 100 and 500 meters above sea level with average annual rainfall is $3065 \mathrm{~mm}$. The characteristic of middle zones is multiple cropping system with combination of paddy fields and annual dry lands crops (BPS, 2018). In this study, lowlands were represented by Kebandungan Village and middle zones were represented by Karangpari Village.

Jabres cattle is kept for in the community hereditarily. Its presence in the community is very meaningful because most of the people in the Bantarkawung Sub-District use it as one of the pillars of their life support. Farmers mentioned the following motivations: financial security (saving), income, providing manure, utilization of crop byproducts, raising the social status of their owner, cultural events, draught purposes and hobby. Most farmers mentioned "saving" as the most important motivation. Farmers consider saving in terms of being able to sell cattle to meet unexpected or large expenditures, such as sending children to school, paying hospital bills for a family member, financing a wedding party or a pilgrimage to Mekka (Widi et al., 2014). Cattle as a livelihood is maintained for business purpose and sold in high value. Farmers optimize all resources to get maximum profits, including produce fertilizer from cattle feces as the second product. The cattle is kept as good as they can, so they can live, reproduce, and produce more manure. The purpose of raising cattle in the community has an important role, especially for developing countries because it can drive market conditions (Moll et al., 2001).

Bantarkawung is one of the breeding center of Jabres cattle in Brebes Regency. This location is contained of lowlands and middle zone. In the discussion of Jabres cattle farming, both region should be differentiated because each region has different strength and weakness. Farming in middle zone has strength of forage abundance, stable price, and the regular extension advice. However, they should compete with other area in selling livestock and limited access to credit. Conversely, farming in lowlands easy to sell their livestock and easy to access credit, but they prone to theft, feed shortage, and lack of labour (Budisatria et al., 2010). Study about farmers profile and their socio-economic benefit in lowlands and middle zone is required to evaluate the sustainability of farming in those region. Therefore, the purpose of this study was to explore, analyze, and compare the socioeconomic benefits (net production, value added, value of manure, the intangible benefits form saving and insurance and total benefit) of Jabres cattle in two agro ecological zones in Bantarkawung Sub-District, Brebes.

\section{MATERIALS AND METHODS}

\section{Description of the Experimental Area}

Bantarkawung is the widest sub-district in the southern part of Brebes Regency, Central Java, Indonesia with an area of $205,000 \mathrm{~km}^{2}$ or $12.33 \%$ of the total area of Brebes Regency. The rainfall in this region is $2,882 \mathrm{~mm}$ with the number of rainy days as many as 163 days. The population density is 393 people $/ \mathrm{km}^{2}$ with total population of 89,158 people in 2016 . Bantarkawung Sub-district was composed by lowlands (less than 100 meters above sea level) and middle zones (between 100 and 500 meters above sea level). In this study, the lowlands were represented by Kebandungan Village and the middle zone were represented by Karangpari Village (BPS, 2018). Lowlands and middle zones data were differentiated in order to explore the effect of region characteristic difference on the socio-economic benefit and sustainability potential of Jabres cattle farming. 


\section{Data Collection Methods}

The farmers profiles consist of name, age, education, occupation, experience in ruminants farming, number of dependents or family member, number of cattle ownership, types of cattle raised and the purpose of raising livestock. In order to analyze the motivation difference of Jabres farmer in both region, each farmer was asked to rank their thought about Jabres cattle importance, whether they thought Jabres cattle is important as saving, main livelihood, or to produce manure. The first rank was rated 3, the second rank was rated 2, and the third rank was rated 1. The farmers profiles are collected from each region by Participatory Rural Appraisal (PRA) methods (Kirsopp-Reed, 1994), where the researcher approaches to families or individuals to analyze the reality of their living conditions. Interviewing is one of the most important methods of gathering information and often forms the core of a good PRA. It used to explore issues arising from participatory exercises and to generate discussions. Interviews and discussions were performed with selected individuals and groups (Kirsopp-Reed, 1994). As many as 30 farmers from each region were selected by purposive sampling based on these considerations (1) having at least one Jabres cattle (male or female), (2) farmers agree and give permission to be object of the research, and (3) location access, where it technically could be used as the location for data collection. Questionnaires are also used as supplementary data.

\section{Function of Livestock}

Jabres cattle has production and socioeconomic functions. In order to explore the total benefit for farmers, some equations needed to calculate the production and socio-economic benefit of Jabres cattle farming. The total benefit value was used to predict the sustainability potential of the farming. Jabres cattle contribution in term of production and socio-economic benefits (financing and insurance benefit) over a period of one year (February 2017 until January 2018) were calculated by using equation described by Ayalew (2000). Estimation of the production calculated as follows:

Table 1. Profile of Jabres Cattle Farmers in Two Agro Ecological Zone in Bantarkawung Subdistrict, Brebes, Central Java, Indonesia (mean \pm standard deviation)

\begin{tabular}{lrc}
\hline \multicolumn{1}{c}{ Parameter } & Lowlands & Middle Zone \\
\hline Farmers number (n) & \multicolumn{1}{c}{30} & 30 \\
Farmers age (year) & $47.33 \pm 9.44$ & $42.97 \pm 7.36$ \\
Farming experience (year) & $23.33 \pm 9.13$ & $22.97 \pm 7.36$ \\
Number of dependent (n) & $4.13 \pm 1.53$ & $4.47 \pm 0.94$ \\
Number of Owned Cattle (n) & $3.33 \pm 1.86$ & $3.50 \pm 2.18$ \\
Education Level & & \\
$\quad$ Not graduated from elementary school (\%) & 46.67 & 46.67 \\
Elementary School (\%) & 30.00 & 36.67 \\
$\quad$ Junior High School (\%) & 16.67 & 13.13 \\
Senior High School (\%) & 6.67 & 3.33 \\
Livestock keeping motivation* & & \\
Savings & $2.90 \pm 0.31$ & $2.70 \pm 0.47$ \\
Livelihood & $1.90 \pm 0.55^{\mathrm{a}}$ & $2.23 \pm 0.50^{\mathrm{b}}$ \\
Manure & $1.20 \pm 0.41$ & $1.07 \pm 0.37$ \\
\hline
\end{tabular}

*Stratified by its importance, where $1=$ not important, $2=$ important, $3=$ very important.

*The different subscript denote significant difference between means within rows based on independent Ttest $(\mathrm{P}<0.05)$ 
Where:

$$
\mathrm{Yk}=\mathrm{FSk}-\mathrm{ISk}+\mathrm{Sk}-\mathrm{Pk}+\mathrm{OTk}-\mathrm{ITk}+\mathrm{Ck}
$$

Yk : Net production of beef cattle $(\mathrm{kg})$

Fsk : Body weight $(\mathrm{kg})$ at the end of the observation

Isk : Body weight $(\mathrm{kg})$ at the beginning of the observation

Sk : Body weight $(\mathrm{kg})$ of all cattles sold

$\mathrm{Pk} \quad$ : Body weight $(\mathrm{kg})$ of all cattles purchased

Otk : Body weight $(\mathrm{kg})$ of all cattles transferred out

Itk : Body weight $(\mathrm{kg})$ of all cattles tranferred in

Ck : Body weight $(\mathrm{kg})$ of all cattle slaughtered

Value added (VA) is calculated using the following equation:

$\mathrm{VA}=(\mathrm{Yk} x$ price per $\mathrm{kg})$ - feed price

The cash variable in this study is only limited to the cost of concentrate feed. Medicines are not counted. In this research, the cash cost and noncash cost in this study did not consider. The price per $\mathrm{kg}$ of the cattle was calculated by the average price received by farmers when they sell cattle divided by total body weight of the cattle. The value of manure (VM) was calculated as the total dry matter of manure produced multiplied by the estimated price per kg dry matter of manure.

$\mathrm{VM}=\mathrm{DM}$ Stool $\mathrm{x}$ price per $\mathrm{kg}$.

The intangible benefits from financing are the product of multiplying the selling price of livestock when the household requires cash and saving transaction costs from borrowing money (Moll, 2005). This benefit is formulated as follows:

$$
\begin{aligned}
& \mathrm{Fk}=\mathrm{OMk} \times \mathrm{F} \\
& \mathrm{Omk}=(\mathrm{Ck}+\mathrm{Sk}+\mathrm{OTk}) \times \text { price per } \mathrm{kg}
\end{aligned}
$$

$\mathrm{Fk}$ : Profit from financing

F : Financing factor for research area $8.5 \%$ (Bank BRI, Central Java, 2018, personal communication)

Omk : Selling price when households need cash Intangible benefits from insurance relate to capital invested in a group as a guarantee to meet unexpected expenses and can be compared with premium insurance (Moll, 2005). Intangible benefits from insurance are expressed as amount per years: where:
Ik : Insurance benefits

Wk : Average cattle weight in one stall $\mathrm{x}$ price per kg

S : Factors of life insurance 10\% (AXA Mandiri Insurance, Central Java, 2018, personal communication)

The total benefit (Y) for keeping Jabres cattle for a period of one year can be estimated by:

$$
\mathrm{Y}=\mathrm{VA}+\mathrm{VM}+\mathrm{Fk}+\mathrm{Ik}
$$

\section{Statistical Analysis}

The result of this research was analyzed statistically to explore the effect of region characteristic difference on the socio-economic benefit and sustainability potential of Jabres cattle farming. The independent t-test analysis model was used to explore the significance of farmers profile and Jabres cattle socio-economic benefit difference between lowlands and middle zones.

\section{RESULTS AND DISCUSSIONS}

The profile of Jabres cattle farmers in two agro ecological zones in Bantarkawung SubDistrict is presented in Table 1. The age of the farmer was closely related to the physical ability to work and receive information. Moreover, the age of the farmers also reflects their farming experience (Suwarto, 2007). In Bantarkawung District, almost all of the farmers in lowlands and middle zone have age of 16-64 years, which are classified as productive age (BPS, 2019). It is a very good fact because productive age farmers can reach high work achievement level (Sudarmanto, 2005; Suratiyah, 2011; Luanmase et al., 2011). In this study, the farmers in middle zone were younger than the farmers in lowlands but not significant $(P=0.05)$. It is important fact because younger farmers are easier to accept innovation when compared to the older ones (Waris et al., 2011).

The farming experience is closely related to the motivation of livestock keeping. The longer farmer experience in keeping livestock will increase its motivation (Luanmase et al., 2011). In addition, the experience of keeping livestock will also influence the selection of market to sell their livestock (Musemwa et al., 2007). Farming experience of lowlands farmers was longer than middle zone farmers, but not significantly different $(\mathrm{P}=0.865>0.05)$. In addition, based on 
Table 2. Production and Socio-economic Benefits of Jabres Cattle in Two Agro Ecological Zone in Bantarkawung Subdistrict, Brebes, Central Java, Indonesia from February 2017 to January 2018 (Mean \pm Standard Deviation)

\begin{tabular}{lcc}
\hline \multicolumn{1}{c}{ Parameter } & Lowlands & Middle Zone \\
\hline Flock size (n) & 3.3 & 3.5 \\
Net production $\left(\mathrm{kg} \mathrm{y}^{-1}\right)$ & $1.955 \pm 309$ & $2.219 \pm 322$ \\
Manure $\left(\mathrm{kg} \mathrm{y}^{-1}\right)$ & $22.622 \pm 4.097$ & $22.205 \pm 5.776$ \\
Benefits: & & \\
Value Added (IDR $\left.10^{3} \mathrm{y}^{-1}\right)$ & $38.643 \pm 12.509^{\mathrm{a}}$ & $58.804 \pm 14.459^{\mathrm{b}}$ \\
Value of Manure (IDR $\left.10^{3} \mathrm{y}^{-1}\right)$ & $2.262 \pm 409$ & $2.220 \pm 577$ \\
Financing (IDR $\left.10^{3} \mathrm{y}^{-1}\right)$ & $3.081 \pm 948$ & $3.161 \pm 445$ \\
Insurance (IDR $\left.10^{3} \mathrm{y}^{-1}\right)$ & $1.005 \pm 141$ & $1.042 \pm 121$ \\
Total Benefits (IDR $\left.10^{3} \mathrm{y}^{-1}\right)$ & $44.992 \pm 13.072^{\mathrm{a}}$ & $65.228 \pm 14.770^{\mathrm{b}}$ \\
\hline
\end{tabular}

* The different subscript indicate significant difference between means within rows based on independent ttest $(\mathrm{P}<0.05)$

the Pearson correlation analysis result, the farmers age has significant correlation with farming experience with Pearson correlation coefficient of 0.967 and 1.000 for lowlands and middle zone, respectively. So it can be concluded that farmers in middle zone have fewer farming experience because they are younger than farmers in lowlands.

The number of dependents or family members of lowlands farmers and the middle zone farmers did not significantly different $(\mathrm{P}=$ $0.313>0.05)$. Wibowo and Haryadi (2006) stated that the number of dependents influences the decision making or attitudes of farmers against a problem related to the economy. Moreover, the farmers decision making or attitude also was influenced by the number of livestock owned. The bigger number of the owned livestock can increase the number of the sold livestock, so that it can improve the economic condition of the farmers (Hanggara et al., 2011; Montshe, 2006).

The level of education has an influence on the tendency of farmers in solving economic problems in their families (Wibowo and Haryadi, 2006; Montshe, 2006). The level of farmer's education in both regions were similar, where farmers who had not graduate from elementary school took the biggest portion, followed by farmers who graduated from elementary school, junior high school, and senior high school, respectively. The lowlands had more junior high school and senior high school graduated farmers than those of the middle zone but not significant $(\mathrm{P}=0.665>0.05)$. However, in both region only a few of higher education graduates who become farmers. It also agreed by Micevska and Rahut (2008) which stated that the higher the education level of people, they tend to leave an agricultural activity as their livelihood. It is very disappointing because education level is very important for farmer competency, thinking method, acceptance and implementation of innovation (Zulfanita et al., 2009). The combination of good education level with great farming experience will produce the right decision making (Suratiyah, 2011).

Most of Jabres cattle farmers thought that cattle are very important as savings. This is the same as the previous research that the majority of Jabres cattle farmers made their cows as savings (Haq et al., 2016). Some of them also used cattle as the main livelihood. Only few of farmers that use cattle to produce manure was as secondary livelihood. This condition occurs in both agro ecological zones. Lowland farmers thought that manure producing was more important than middle zone thought about manure, but the difference was not significant $(P=0.187>0.05)$. However, livestock as savings is more important in the lowland but not significant $(\mathrm{P}=0.054>$ 0.05) compared to the middle zone, while 
livestock as a livelihood is significantly more important in the middle zone $(\mathrm{P}=0.017<0.05)$ than in the lowland zone. It is due to the distance of the animal market is closer to the middle zone than the lowlands. The middle zone farmers prefer to sell their livestock in the market rather than keep the livestock as saving while lowland farmes prefer to keep their livestock as saving rather than sell the livestock in the market. This condition also happened in Northeast Thailand where smallholder beef cattle farmer primarily kept livestock in order to cover expected and unexpected expenses and to generate supplementary rather than main livelihood (Lambertz et al., 2012).

\section{The Value of Social and Economic Benefits of Jabres Cattle}

The socio-economic benefits of keeping cattle are very important to survive on small-scale livestock (Ouma et al., 2003). The obtained intangible benefit can help farmers to improve the sustainability of their farms (Moll et al., 2001; Moll, 2005). The production and socio-economic benefits of Jabres cattle in two different agro ecological zones are presented in Table 2. Between the lowland and middle zone, the flock size did not have a significant difference, but net production in the middle zone was higher but not significant $(\mathrm{P}=0.095>0.05)$ compared to net production in the lowlands. Net production in the middle zone was $13.5 \%$ greater than of the lowlands. This difference can occur because middle zone farmers have higher flock size and closer distance to market than lowlands farmers. The same result was also obtained by Budisatria (2006) who explored the socio-economic benefits of small ruminants flocks in three agro ecological zone in Central Java. This had an impact on the significant difference of value added in both regions $(\mathrm{P}=0.006<0.05)$. The added value in the middle zone was contributing $52.2 \%$ higher than of the lowlands. The amount of value added in both region is much higher than the minimum wage of labour in Brebes City, namely IDR 1.542.000 per month (Gubernur Jawa Tengah, 2018). It means that farmers can live adequately in their area even if only by farming.

The difference of the area condition between the lowlands and the middle zone has its own role in determining the farmer purpose of keeping cattle. Most breeders in the lowlands make livestock as savings, while in the middle zone livestock is also used as a livelihood. This difference results in the different management system of livestock. Farmers who have stronger goal purpose will have better farms (O'Rourke et al., 2012). Based on the statistical analysis, there is no significant difference between the production of cattle manure, the selling value of cattle manure, financing, and insurance value in both region. However, the financing and insurance value in the middle zone is higher than of the medium land as much as $2.59 \%$ and $3.68 \%$, respectively. The financing and insurance value influence the total benefit which can be obtained by the farmers (Moll, 2005). The financing value is important for farmers because it enables households to meet their expected expenditure needs by converting the part of the cattle into disposable livelihood and vice versa. The insurance value is important in maintaining the livestock to guarantee for unexpected expenses in the future (Ouma et al., 2004). The amount of financing and insurance value contributed $54.52 \%$ and $45.26 \%$ of the amount of total benefit for farmers in lowlands and middle zone, respectively. It is consistent with the saving motivation of farmers in keeping cattle. The financing and incurance contribution of total benefit for middle zone farmers is less than lowlands farmers because middle zone farmers used cattle as livelihood more than lowlands farmers. Moreover, the total benefit in the middle zone farmers is $23.9 \%$ higher than the lowlands farmers $(\mathrm{P}=0.040<0.05)$. However, the total benefits are related to household characteristics that may differ substantially, such as household composition, education, farming experience and number of owned cattle (Moll, 2005). The total benefits are reflected in the higher values for value added, financing and insurance for Jabres cattle in the midlle zone (Budisatria, 2006). Based on these reasons, it can be concluded that middle zone farmer have more possibility to sustain their farm than lowlands farmers.

\section{CONCLUSION}

The socio-economic benefit of Jabres cattle farmers in two ecological zones in Bantarkawung Sub-District, Brebes, Central Java has been explored using PRA Methods, analyzed using estimation of production and total benefit equations and compared using statistical analysis. Middle zone farmers had stronger livestock keeping motivation for their livelihood than lowlands farmers. Middle zone farmers also had 
higher socio-economic benefit than lowlands farmers due to their higher added value in total benefit calculation. Based on these results, it can be concluded that middle zone farmers have more possibility to sustain their farm than lowlands farmers.

\section{ACKNOWLEDGMENTS}

The authors expressed special thanks to Ministry of Research and Higher Education of Indonesian Republic which has partly supported this research activities through Universitas Gadjah Mada, Yogyakarta, by providing scholarship of Master Education Program Leading to Doctoral Degree for Excellent Graduates (PMDSU) to the first author with contract number of 2046/UN1/DITLIT/DIT-LIT/LT/2018.

\section{REFERENCES}

Ayalew, W. K. 2000. Do smallholder farmers benefit more from crossbred (Somali $\mathrm{x}$ Anglo-Nubian) than from indigenous goats? $\mathrm{PhD}$ Thesis. Georg-August University of Gottingen, Gottingen.

BPS (Badan Pusat Statistik = Indonesian Central Agency for Statistics). 2018. Brebes Regency in Figure. BPS-Statistics of Brebes Regency, Brebes

BPS (Badan Pusat Statistik = Indonesian Central Agency for Statistics). 2019. Istilah Angka Beban Tanggungan (Term for Dependents Number).

Budisatria, I.G.S. 2006. Dynamic of small ruminant development in Central Java, Indonesia. $\mathrm{PhD}$ Thesis. Wageningen University, Netherlands.

Budisatria, I.G.S., H.M.J. Udo, C.H.A.M. Eilers, E. Baliarti and A.J., van der Zijpp. 2010. Preferences for sheep or goats in Indonesia. Small Ruminant Res. 88(1):16-22.

Gubernur Jawa Tengah. 2017. Keputusan Gubernur Jawa Tengah No. 560/94 Tahun 2017 tentang upah minimum pada 25 kabupaten/kota di Provinsi Jawa Tengah Tahun 2018 (Decision of Central Java Governor No. 560/94 Year 2017 concerning minimum wages in 25 districts / cities in Central Java Province in 2018). http://www.semarangkab.go.id/utama/image s/stories/data/UMK-Jateng-2018.pdf Accessed February 3, 2019.
Hanara, G.N., M. Y. Teweldemedhin and I.B. Groenewald. 2011. Measuring factors that can influence cattle supply response to the market in Namibia: Case study from Omaheke communal farmers. J. Agric. Ext. Rural Dev. 3(8):141-146.

Haq, M. S., I. G. S. Budisatria, Panjono and D. Maharani. 2016. Farmer Profiling of Jabres Cattle at Breeding Center in Bantarkawung, Brebes, Central Java Province, Indonesia. Int. J. Agric. Forestry \& Plantation. 4:51-55.

Kirsopp-Reed, K. 1994. A review of PRA methods for livestock research and development. RRA Notes 20: 11-36. IIED, London.

Lambertz, C., C. Chaikong, J. Maxa, E. Schlecht and M. Gauly. 2012. Characteristics, socioeconomic benefits, and household livelihoods of beef buffalo and beef cattle farming in Northeast Thailand. J. Agr. Rural Dev. Trop. 113(2): 155-164.

Luanmase, C.M., S. Nurtini and F.T. Haryadi. 2011. Analisis motivasi beternak sapi potong bagi peternak lokalransmigran serta pengaruhnya terhadap pendapatan di Kecamatan Kairatu, Kabupaten Seram bagian barat (Analysis of motivatio to raise beef cattle for migrant local farmers and their effect on livelihood in Kairatu Subdistrict, West Seram Regency). Buletin Peternakan. 35(2):113-123

Micevska, M. and D.B. Rahut. 2008. Rural nonfarm employmnet and livelihoods in the Himalayas. Econ. Dev. Cult. Change. 57(1):163-193.

Moll, H.A.J. 2005. Costs and benefits of livestock systems and the role of market and nonmarket relationships. Agr. Econ. 32: 181-193.

Moll, H.A.J., S.J. Staal and M.N.M Ibrahim. 2001. From Meat to Milk: Smallholders' Livelihoods and Markets. Proc. 12th Symposium Tropical Animal Health and Production, Dairy Development in the Tropics, University of Utrecht. P:1-15.

Montshwe, B.D. 2006. Factors affecting participation in mainstream cattle markets by small-scale cattle farmers in South Africa. Thesis. University of Free State, Bloemfontein.

Musemwa, L., Chagwiza C., Sikuka W., Fraser G., Chimonyo M. and Mzileni N. 2007. Analysis of cattle marketing channels used by small scale farmers in the Eastern Cape 
Province, South Africa. Livestock. Res. Rural. Dev. 19(9):131

O'Rourke, E., Kramm N. and Chisholm N. 2012. The influence of farming styles on the management of the Iveragh uplands, Southwest Ireland. Land. Use. Policy. 29: 805-816.

Ouma, E.A., G.A. Obare and S.J. Staal. 2003. Cattle as assets: assessment of non-market benefits from cattle in smallholder Kenyan crop- livestock systems. Proc. 25th International Conference of Agricultural Economists (IAAE), Durban, South Africa, August 16-22, 2003 P. 328-334.

Ouma, E.A., G.A. Obare and S.J. Staal. 2004. The Socio-economic dimensions of smallholder livestock management in Kenya and its effects on competitiveness of crop-livestock systems. Proc. of NARO Conference on "Integrated Agricultural Research for Development-Achievements, Lessons Learnt and best Practice", Uganda, September 1-4, 2004. P.1-16.

Sudarmanto, B. 2005. Produktivitas tenaga kerja keluarga dalam pemeliharaan sapi Perah di Kecamatan Gatesan, Kabupaten Semarang (Family labor productivity in maintaining dairy cattle in Gatesan District, Semarang Regency). Thesis. Universitas Gadjah Mada, Yogyakarta.

Suratiyah, K. 2011. Ilmu usahatani (The science of farming). PT. Penebar Swadaya, Jakarta.

Suwarto. 2007. Kelembagaan lahan dan tenaga kerja pada usahatani tanaman pangan di Kabupaten Gunung Kidul (Institution of land and labor in food crop farming in south zone of Gunung Kidul Regency). PhD
Thesis. Universitas Gadjah Mada, Yogyakarta.

Waris, N. Badriyah, dan D. Wahyuning. 2015. Pengaruh tingkat pendidikan, usia, dan lama beternak terhadap pengetahuan manajemenreproduksi ternak sapi potong di Desa Kedungpring Kecamatan Balongpanggang, Kabupaten Gresik (Effect of Education Level, Age, and Length of Livestock Raising on Management Knowledge of Reproduction of Beef Cattle in Kedungpring Village, Balongpanggang Subdistrick, Gresik Regency). Jurnal Ternak. 06(1): 30-33.

Widi, T. S. M., H. M. J. Udo K. Oldenbroek, I. G. S. Budisatria, E. Baliarti and A. J. van der Zijpp. 2014. Unique cultural values of Madura cattle: is cross-breeding a threat?. Anim. Genet. Resour. 54: 141-152.

Wibowo, S.A. and F.T. Haryadi. 2006. Faktor karakteristik peternak yang mempengaruhi sikap terhadap program kredit sapi potong di Kelompok Peternak Andiniharjo, Kabupaten Sleman Yogyakarta (Characteristics of Breeders that influence attitudes towards beef cattle credit program in the Andiniharjo Farmer Group, Sleman Regency, Yogyakarta). Media Peternakan. 29(3):176-186.

Zulfanita, M.A. Wiguna and S. Nurtini. 2009. Evaluasi usaha penggemukan sapi potong gaduhan di Desa Grantung, Kecamatan Bayan, Kabupaten Purwarejo (Evaluation of the effort to fatten Gaduhan beef cattle in Grantung Village, Bayan District, Purwarejo Regency). Buletin Peternakan. 33(1):57-63. 